\section{Rooting and Survival Potential of Hardwood Cuttings of 406 Species, Cultivars, and Hybrids of Prunus}

\author{
Gregory L. Reighard ${ }^{1}$, David W. Cain ${ }^{2}$, and William C. Newall, Jr. ${ }^{3}$ \\ Department of Horticulture, Clemson University, Clemson, SC 29634
}

Additional index words. vegetative propagation, peach, plum, almond, sand cherry

\begin{abstract}
More than $\mathbf{4 0 0}$ genotypes of Prunus were evaluated for "in field" rooting and survival from fall-planted hardwood cuttings treated with 2000 ppm IBA. Cultivars of European and Japanese plums originating from species and interspecific hybrids of the section (sect.) Prunus had the highest survival. Cuttings from cultivars of sand cherry (sect. Microcerasus) and peach (sect. Euamygdalus) averaged $28 \%$ to $54 \%$ lower survival than European and Japanese plums. Few cultivars of almonds (sect. Euamygdalus), apricots (sect. Armeniaca), and American plums (sect. Prunocerasus) rooted from hardwood cuttings. Chemical name used: 1H-indole-3-butyric acid (IBA).
\end{abstract}

Propagation of peach [Prunus persica (L.) Batsch] by hardwood cuttings has been studied in recent years due to the need for an inexpensive method to produce many trees for high-density orchard systems. Techniques to produce peach cultivars from semihardwood cuttings have been successful but costly under greenhouse conditions (Couvillon and Erez, 1980; Overcash et al., 1983; Erez, 1984; Lohnes, 1986). For rootstock, however, selecting for self-rooting has been necessary in progeny that originate from selfincompatible plum lines, interspecific crosses, and mutations because inherited traits segregate if these rootstock are seed propagated, and many interspecific hybrids are highly sterile. Much of the Prunus germplasm available in the United States has not been tested for its ability to root from hardwood cuttings under field and nursery conditions. This information is needed to determine the feasibility of mass clonal production of desirable genotypes of Prunus and to identify germplasm sources that root easily for use in breeding programs. The objective of this study was to determine the potential for vegetative propagation from hardwood cuttings of a wide range of Prunus genotypes, including plant introductions, numbered selections, species, cultivars, rootstock, and interspecific hybrids.

From a germplasm repository of Prunus at the Sandhill Research and Education Center in Pontiac, S. C., 406 genotypes of Prunus were selected and categorized by species

Received for publication 7 Aug. 1989. Technical Contribution no. 3021 of the South Carolina Agricultural Experiment Station. The assistance of W.R. Okie in identifying the lineage of hybrid cultivars is gratefully acknowledged. The cost of publishing this paper was defrayed in part by the payment of page charges. Under postal regulations, this paper therefore must be hereby marked advertisement solely to indicate this fact.

'Assistant Professor.

${ }^{2}$ Former Peach Breeder. Current address: Superior Farming Co., P.O. Box 80298, Bakersfield, CA 93380

${ }^{3}$ Technician. tions (sect.) [Armeniaca (Lam.) Koch, Euamygdalus (L.) Focke, Microcerasus (Spach) Schneid., Prunocerasus Koehne, Prunus Benth. and Hook] according to Rehder (1940) and Krussmann (1986). Intersectional hybrids were placed in separate categories listing all sections represented in the cross. Genotypes from the five taxonomic sections and three intersectional hybrid groups were further categorized according to one of 12 fruit types to distinguish them by fruit characteristics within and among taxonomic sections.

Twenty-five, 20 -cm hardwood cuttings $\approx 1$ $\mathrm{cm}$ in diameter were taken in November from current year's growth of each of 272, 341, 240 , and 375 genotypes in 1984, 1985, 1986, and 1987, respectively. Cuttings were bundled, labeled, wrapped with moist paper towels, and transported in insulated coolers composition into one of five taxonomic secof Prunus field-tested for 4 consecutive years. Data are 4-year means.

"Mean separation by Tukey's student range test $P=0.05$. to Clemson, S. C., where they were treated and stuck the following day. Before treating, each cutting was wounded with two equidistant 5 -cm vertical incisions through the bark and cambium at the base of the cutting. Cuttings were subsequently dipped to $1 \mathrm{~cm}$ above the incisions for $10 \mathrm{sec}$ in $2000 \mathrm{ppm}$ IBA dissolved in a solution of $50 \%$ ethanol and $50 \%$ distilled water. Following IBA treatment, cuttings were inserted through a black plastic mulch to a depth of $10 \mathrm{~cm}$ in a fumigated, tilled Cecil (clayey, kaolinitic, thermic, Typic Hapludults) sandy loam soil. After March budbreak, water was applied twice weekly via a trickle-irrigation system to maintain adequate soil moisture for vegetative growth.

Percent survival was recorded the following July for each set (year). of cuttings. Cultivars ( = genotypes) were grouped according to fruit type within taxonomic sections, and survival data of each cultivar and fruit type were arcsin transformed for data analysis. Cultivar and fruit type data were analyzed as a randomized block design, with each year treated as a replicate. Tukey's student range test was used to separate fruit type means because of unequal numbers of cultivars per fruit type.

Survival of the hardwood cuttings differed significantly among cultivars (data not presented) and fruit types (Table 1) at the $0.1 \%$ level. Statistically, there was no strong separation among fruit types for survival, although European and Japanese plum cultivars from sect. Prunus (P. cerasifera Ehrh, $P$. domestics L., P. insititia L., P. salicina Lindl., $P$. simonii Carr., P. spinosa L.) and intersectional hybrids involving American plum species ( $P$. americana Marsh., $P$. angustfolia Marsh., $P$ hortulana Bailey, $P$. maritima Marsh., P. munsoniana F.W. Wight $\&$ Hedr.) from sect. Prunocerasus generally

Table 1. Mean arcsin values and percent survival of hardwood cuttings from 12 groups of fruit types

\begin{tabular}{|c|c|c|c|c|}
\hline $\begin{array}{l}\text { Fruit type } \\
\text { grouping }\end{array}$ & $\begin{array}{l}\text { Taxonomic } \\
\text { section }\end{array}$ & $\begin{array}{l}\text { No. of } \\
\text { cultivars }\end{array}$ & $\begin{array}{l}\text { Mean survival } \\
\text { for } 4 \text { years } \\
(\%)\end{array}$ & $\begin{array}{c}\text { Arcsin } \\
\text { value }^{z, y}\end{array}$ \\
\hline $\begin{array}{l}\text { European and } \\
\text { Japanese plum }\end{array}$ & Pnunus & 41 & 42.5 & $39.0 \mathrm{a}$ \\
\hline $\begin{array}{l}\text { European and } \\
\text { Japanese plum } \times \\
\text { American plum }\end{array}$ & $\begin{array}{l}\text { Prunus } \times \\
\quad \text { Prunocerasus }\end{array}$ & 27 & 40.3 & 37.4 a \\
\hline $\begin{array}{l}\text { European and } \\
\text { Japanese plum } \\
x \text { sand cherry }\end{array}$ & $\begin{array}{l}\text { Prunus } x \\
\quad \text { Microcerasus }\end{array}$ & 7 & 36.2 & $33.6 \mathrm{ab}$ \\
\hline Sand cherry & Microcerasus & 10 & 30.7 & $30.3 \mathrm{ab}$ \\
\hline $\begin{array}{l}\text { European and } \\
\text { Japanese plum } \\
x \text { peach }\end{array}$ & $\begin{array}{l}\text { Prunus } \mathrm{x} \\
\quad \text { Euamygdalus }\end{array}$ & 7 & 28.1 & $29.1 \mathrm{abc}$ \\
\hline Peach-like & Euamygdalus & 14 & 23.9 & $24.1 \mathrm{abcd}$ \\
\hline Peach $x$ almond & Euamygdalus & 18 & 23.3 & $24.0 \mathrm{abcd}$ \\
\hline Peach & Euamygdalus & 220 & 22.5 & $24.0 \mathrm{abcd}$ \\
\hline Nectarine & Euamygdalus & 22 & 19.6 & $20.6 \mathrm{abcd}$ \\
\hline American plum & Prunocerasus & 11 & 8.5 & $11.4 \mathrm{bcd}$ \\
\hline Apricot & Armeniaca & 16 & 3.5 & $5.5 \mathrm{~cd}$ \\
\hline Almond & Euamygdalus & 13 & 1.5 & 3.6 \\
\hline
\end{tabular}

${ }^{2}$ Values represent percent survival data that were arcsin transformed to degrees for analysis of variance.

${ }^{x}$ Peach-like includes the species P. davidiana, P. kansuensis, and P. triloba. 
Table 2. Top 10 surviving cultivars of peach and plum tested for at least 3 of 4 years.

\begin{tabular}{lclc}
\hline \hline Cultivar & $\begin{array}{c}\text { Mean } \\
\text { survival } \\
(\%)\end{array}$ & \multicolumn{1}{c}{$\begin{array}{c}\text { Cultivar } \\
\text { of peach }\end{array}$} & $\begin{array}{c}\text { Mean } \\
\text { survival } \\
(\%)\end{array}$ \\
\hline of plum & 96 & Rheingold & 60 \\
Early Crimea & 91 & Chico 11-12 & 60 \\
St. Julian & 90 & PI 146137 (USSR) & 55 \\
WA 1236 & 88 & ARK 7768 & 50 \\
Marianna 2624 & 82 & Chu Hun Tao & 46 \\
SJ 53-7 & 81 & Hangchow & 44 \\
WA 1230 & 74 & Nectar & 44 \\
Damas 1869 & 73 & Yennoh & 43 \\
Ohio 2 & 73 & Tenn. Nat. IR 282-2-6 & 42 \\
Myrobalan B & 72 & Heath Cling & 41 \\
FL 1-2 Plum & & &. \\
\hline
\end{tabular}

had higher survival rates. Some cultivars of European plums had excellent survival, especially when compared with the best cultivars of peach (Table 2).

Sand cherry cultivars from $P$. besseyi Bailey and P. pumila L. (sect. Microcerasus) had lower survival rates $(31 \%)$ than those of the European and Japanese plums. Likewise, peach, nectarine, and related peach-like species [P. davidiana (Carr.) Franch., P. kansuensis Rehd., P. triloba Lindl.] from sect. Euamygdalus also had lower survival rates ( $20 \%$ to $24 \%$ vs. $40 \%$ to $43 \%$ ) than the European and Japanese plums, but these differences were not statistically different. Survival in the almonds [P. dulcis (Mill.) D.A. Webb (= P. amygdalus Batsch), $P$. fenzliana Fritsch], apricots ( $P$. armeniaca L., $P$. mume Sieb. and Zucc.), and American plums (sect. Prunocerasus), in contrast, was poor (2\% to $9 \%$ ) and significantly lower than any fruit type from the Prunus and Microcerasus sections. Mean survival of each intersectional hybrid group was intermediate to their two parent groups.

Cutting survival was also significantly influenced by year. Cuttings stuck in Nov. 1986 had significantly higher survival (33\%) than those stuck in $1984(20 \%), 1985(23 \%)$, or $1987(18 \%)$. Mean soil temperatures at the 10-cm depth, however, did not differ more sampled in 1986, which would inflate the overall survival rate, as compared to the other years. Other factors that were not quantitatively measured, such as mother-tree vigor and winter rainfall, also may have influenced rooting and survival of the 1986 cuttings.

Data suggest hardwood cuttings are a potential means to propagate many selections of Prunus from sects. Prunus and Microcerasus, since 18 of the 20 cultivars with $>60 \%$ survival were plum and sand cherry cultivars and hybrids. Results are less encouraging for hardwood propagation of selections from the sect. Euamygdahs. Propagation success for peach, nectarine, and intrasectional hybrids varied widely among and within species. Cultivars derived from $P$. persica generally propagated more successfully from hardwood cuttings than those from lineages containing $P$. davidiana, $P$. dulcis, and $P$. triloba. However, only $3 \%$ of the peach and nectarine cultivars had greater than $50 \%$ survival.
Similar low-survival rates of field-propagated peach cultivars were reported by Sen and Couvillon (1983) and Matta and Vadhwa (1987). Despite the low propagation success under field conditions, sufficient variation in rooting ability still exists within peach germplasm to suggest that progress could be made toward increasing rooting potential using current breeding techniques. This approach has been successful in plums, as eight of the top 10 surviving cultivars in this study were plum rootstock that were screened by breeders for self-rooting potential. Other means, such as incorporating genes of plums from sect. Prunus into peach by hybridization, might increase rooting and survival of hardwood cuttings. Once genetic barriers to self-rooting in peach are overcome and vegetative propagation techniques improve, production of peach cultivars from hardwood cuttings may become commercially viable in the nursery industry.

\section{Literature Cited \\ Couvillon, G.A. and A. Erez. 1980. Rooting, sur-} vival, and development of several peach cultivars propagated from semi-hardwood cuttings.

Erez, A. 1984. Improving the rooting of peach hardwood cuttings under field conditions. HortScicnce 9:245-247.

Krussmann, G. 1986. Manual of cultivated broadleaved trees and shrubs. vol. 111. Timber Press, Portland, Ore.

Lohnes, J.P. 1986. own-rooted peach and nectarine production. The Grower 19(11):44-46.

Matta, F.B. and O.P. Vadhwa. 1987. Rooting and survival of semi-hardwood peach cuttings under field conditions. Mississippi Agr. and For. Expt. Sta. Res. Rpt. 12(14):1-3.

Overcash, J. P., K. Hancock, and M. Galindo. 1983. Patio peach trees from cuttings. Mississippi Agr. For. Expt. Sta. Bul. 915.

Rehder, A. 1940. Manual of cultivated trees and shrubs. 2nd. ed. Macmillan, New York.

Sen, M.S. and G.A. Couvillon. 1983. Factors affecting survival of "in field", rooted hardwood peach cuttings. HortScience 18:324-325. HortScicnce 15:41-43. 